\title{
POWRÓT JEZUITÓW DO GALICJI
}

W dniu 1 maja 1820 r. 12 jezuitów wygnanych z Mohylowa nad Dnieprem w Rosji stanęło na granicy austriacko-rosyjskiej w Brodach, w ówczesnej wschodniej Galicji. Wkrótce na tym samym przejściu granicznym mieli się zjawić inni ich wspólbracia, wygnani z imperium carów na mocy ukazu cara Aleksandra I z dnia 13/25 marca $1820 \mathrm{r}$. Ku ich zaskoczeniu straż graniczna nie pozwoliła im opuścić Brodów, dopóki nie otrzyma odpowiednich instrukcji od austriackich władz gubernialnych ze Lwowa. Odpowiedź nadeszła, jako że 5 maja t.r. gubernator Galicji Franz baron von Hauer (1815-1822) polecil otworzyć granice austriackie dla jezuitów i przy współpracy z metropolita Iwowskim ob. lac. Andrzejem Alojzym Ankwiczem przygotowal im tymczasowy pobyt $w$ klasztorach lwowskich?.

W Galicji odczuwano ogromny brak księży. Tylko w archidiecezji lwowskiej ob. lac. 70 placówek duszpasterskich było nieobsadzonych i obslugiwanych przez sąsiednie parafie. Stąd to $\mathrm{w}$ archidiecezji tej stosunkowo często pracowali w charakterze wikariuszy kapłani uniccy. W diecezji przemyskiej ob. lac., na laczna liczbe 362 placówek duszpasterskich i 765700 katolików, było zaledwo 407 kapłanów diecezjalnych, a w diecezji tarnowskiej na 337 placówek duszpasterskich 948828 katolików, tylko 417 kapłanów diecezjalnych. Niedobory księży $w$ tej diecezji wedlug relacji biskupa G.T. Zieglera wynosily 202 kapłanów. W latach 1812-1820 wyświęcono w Galicji dla trzech diecezji tylko 150 księży, a więc przeciętnie na jedna $z$ tych diecezji przypadało 5 kapłanów rocznie, gdy tymczasem ubytki na skutek śmierci starszych księży byly daleko większe. Nic dziwnego, że niedobory wzrastały z każdym rokiem².

1 St. Zalęski, Jezuici wo Polsce. Kraków 1908 s. 274; E. Winter, Russland und Papsttum. Berlin 1961. Th. 2 s. $128 \mathrm{n}$.

2 B. Kumor, Ustrój i organizacja Kościoła polskiego w okresie niezoli narodowej 1772-1918. Kraków 1980 s. $451 \mathrm{n}$. 
W tej sytuacji biskupi galicyjscy - arcybiskup metropolita A.A. Ankwicz ze Lwowa (1815-1833), biskup Antoni Golaszewski z Przemyśla (1786-1824) i biskup Grzegorz Tomasz Ziegler z Tyńca-Tarnowa (1821-1827) chętnie przyjmowali jezuitów-wygnaniców, jako że widzieli w nich upragnionych pracowników $w$ duszpasterstwie parafialnym. Tak też sprawe przedstawial metropolita Anwicz w liście do ces. Franciszka I w maju 1920 r., kiedy prosil o zezwolenie jezuitom na osiedlenie się w Galicji i podjęcie przez nich pracy w duszpasterstwie parafialnym ${ }^{3}$.

Suplika metropolity Ankwicza trafila do rak hrabiego Franza Saurau, kanclerza Nadwornej Kancelarii, typowego reprezentanta reżymu józefińskiego. On też $w$ dniu 25 maja 1820 r. skierowal na ręce ces. Franciszka I memorandum o charakterze antyjezuickim, przygotowane mu przez radce państwowego ks. prałata Marcina von Lorenza. Memorandum to głosiło: „w sprawie jezuitów, którzy przyjeżdżaja z Rosji należy tak postępować: zakon ten nie istnieje w moich państwach, dlatego każdy z jezuitów, który będzie chciał opuścić zakon i cieszyl się opinią nieposzlakowanej moralności i gruntownym wyksztalceniem, będzie mial pełna możliwość podjęcia pracy w duszpasterstwie $w$ moich krajach, o ile podporządkuje się obowiązującym przepisom prawnym $w$ tych krajach. To moje rozporządzenie należy tak rozumieć, że ci jezuici, którzy nie zechcą pozostać w moich krajach, maja wolny przejazd przez te kraje". Podsunięty cesarzowi koncept takiego rozwiązania sprawy jezuitów, "przyjął on do wiadomości" (25 maja 1820)․

Tymezasem w dniu 23 maja 1820 r. część jezuitów ku zaskoczeniu metropolity Ankwicza opuścila Lwów i udala się przez Austrię do Wloch. Równocześnie prowincjal bialoruski jezuitów ks. Stanislaw Świętochowski, wychodzac naprzeciw życzeniom metropolity Ankwicza wysłał do Wiednia o. Landesa Bawarczyka w celu przeprowadzenia odpowiednich pertraktacji na temat pozostania i działalności jezuitów $w$ Galicji. O. Landes znalazl w biskupie przemyskim A. Gołaszewskim goracego zwolennika zakonu. Przyjacielem zakonu okazal się również metropolita wiedeński Antoni hr. Hohenwart (1803-1820), dawny jezuita, który przed zniesieniem zakonu w $1773 \mathrm{r}$. pracowal w nim przez 25 lat. Toteż uważał za swój osobisty obowiązek, by nie tylko przyjać o. Landesa do swej rezydencji, ale również, by mu otworzyć drzwi $w$ Wiedniu do odpowiednich ludzi i urzędów. Do przyjaciól zakonu naieży zaliczyć również ówczesnego nuncjusza apostulskiego $w$ Vivieúniu, arcybiskupa Paolo Leardi, jednego z pionierów restauracji katolickiej w Austrii. On to "otworzyl jezuitom drzwi do wielu wybitnych osobistości Wiednia" (F. Maass). Wraz z o. Landesem ponowil prośbę $w$ Wiedniu o pozostawienie

3 F. Maass, Der Josephinismus. Quellen zu seiner Geschichte in Osterreich 1760-1850. Bd. 5. Lockerung und Aufhebung des Josephinismus 1820-1850. Wien 1961 s. 74 n.

+ HHSt. Wien (Hof- Haus- und Staatsarchiv. Vien) St. R. Protocoll $1820 \mathrm{nr}$ 3280, 3455. 
jezuitów w Galicji ówczesny jej gubernator, który na początku czerwca 1820 r. znalazl się $w$ Wiedniu ${ }^{5}$.

Gubernator Hauer wręczyl prośby metropolity Ankwicza osobistemu lekarzowi ces. Franciszka I, Andrzejowi baronowi Stiftowi. Fakt ten mial decydujace znaczenie dla tej sprawy, jako że baron Stift, będacy równocześnie referentem rządowym, był szczerym przyjacielem zakonu i on miał odegrać glówna i pozytyrwną rolę $w$ osiedleniu się redemptorystów $w$ Wiedniu. On też mial zneutralizować antyjezuickie nastawienie kanclerza Saurau i ks. pralata Lorenza, wysuwając „jezuitów nowych" na głównych duszpasterzy młodzieży w krajach austriackich. Jego też opinia o jezuitach i prośby metropolity Ankwicza dokonaly zmiany w postawie ces. Franciszka I wobec sprawy jezuitów. Zgodnie też $z$ jego sugestią ces. Franciszek I zdecydował, że jezuici znając język polski i sami będąc Polakami staną się najlepszymi wychowawcami polskiej mlodzieży w Galicji. Na poczatku sierpnia 1820 r. przybył do Wiednia sam prowincjal ks. St. Świętochowski. Jemu też na osobistej audiencji w dniu 7 sierpnia 1820 r. oświadczyl cesarz: „Dobrze się stało, że nowi jezuici powędrowali do Wloch. Wy będziecie mieć młodych kandydatów z Galicji. Ja bowiem życzę sobie dawnych jezuitów takich, jakimi są. Ci bowiem, którzy wyjechali do Wloch są "nowymi jezuitami". Czy stało się dobrze, tego nie wiem, ale ja życzę sobie dawnych jezuitów"6.

$W$ tym też duchu ces. Franciszek I napisal wlasnoręczny list do kanclerza Nadwornej Kancelarii hr. Sauraua w dniu 12 sierpnia. W liście tym cesarz pisał m.in.: "Kochany Hrabio Saurau jest moim życzeniem, by w Tarnowie w Galicji (sic) przy tworzącym się gimnazjum i studium filozoficznym, przy którym w przyszłości zostanie zorganizowany konwikt, osiedli jezuici i to gimnazjum zostało im powierzone, im - wygnańcom z Rosji. Zechce Pan, Hrabio, jak najszybciej spotkać się z bawiącym z Wiedniu prowincjalem jezuitów, lub z jego pelnomocnikiem i ustalić liczbę jezuitów i wszelkie warunki dla utworzenia jezuickiego kolegium $w$ Tarnowie. Zechce też Pan, Hrabio, wplynąć na prowincjala, lub jego pelnomocnika, by jezuici i ci wyznaczeni do Tarnowa, jak i ci, którzy wciąż przybywaja z Rosji do Galicji, nie kontynuowali swej podróży, lecz zatrzymali się w Galicji"7. O tej decyzji cesarskiej Kancelaria Nadworna powiadomiła poszczególnych biskupów austriackich ${ }^{8}$.

Pismo cesarskie nie precyzowało żadnych warunków, a osobista wypowiedź ces. Franciszka I wyraźnie stwierdzała, że chce on mieć „dawnych jezuitów”. Warunki założenia kolegium jezuickiego w Tarnowie omówiono już 10 sierp-

5 St. Zalęski, Jezuici, s. 274; E. Tomek, Kirchentgeschichte Ôsterreichs. Th. 3. Innsbruck 1959 s. $537 \mathrm{n}$.

6 F. Maass, Der Josephinismus, s. 76.

7 F. Maass, Der Joscphintismus, nr 4 s. 182.

8 E. Tomek, Kirchengeschichte, Th. 3 s. 647. 
nia, ale nie można bylo przystapić do ich realizacji, ponieważ cesarz postanowieniem $z$ dnia 20 sierpnia 1820 r. polecil założyć jezuickie kolegium i studium filozoficzne $w$ Tarnopolu $w$ archidiecezji lwowskiej. $W$ piśmie, skierowanym do hr. Saurau cesarz oświadczyl, że „50 jezuitów, którzy będą pracować w tymże kolegium wraz z prowincjalem" bierze na utrzymanie funduszu religijnego, że „podobne kolegium jezuickie winno być otwarte w innym mieście Galicji, oraz, że ile to jest możliwe, by jezuitów angażować do pracy w duszpasterstwie". Na pierwsze potrzeby kolegium tarnopolskiego cesarz przeznaczyl 4000 flor. ren. a jako uposażenie dla 50 jezuitów - 300 flor. ren. na jedną glowę rocznie do dnia 1 września 1820 r. Uwalnial równocześnie jezuitów, podobnie jak i inne zakony pracujące w szkolnictwie (pijarzy, urszulanki) od prawa mamoratazycyjnego, ale też stwierdzal, że „jezuici sa zobowiązani przestrzegać dokładnie przepisów państwowych w zakresie studiów in publico ecclesiasticis". Wskazywal też $w$ jakim zakresie moga oni liczyć na pewne dyspensy, by "mogli zatrzymać istotne przepisy swoich statutów (reguły) i swego Instytutu". Kolegium jezuickie wraz z konwiktem miało być otwarte jeszcze we wrześniu 1820 r. przy wspólpracy gubernatora Galicji barona Hauera. Toteż jeszcze 6 listopada 1820 r. jezuici otworzyli $w$ Tarnopolu kolegium $i$ gimnazjum $z$ niemieckim językiem wykladowym, a w 1823 r. również dwuletnie studium filozoficzne również $z$ niemieckim językiem wykładowym.

Czy ces. Franciszek I zdawał sobie sprawę, że przyjęcie "dawnych jezuitów", którzy mogli pracować zgodnie „z istotnymi przepisami swej reguly i Instytutu" stanowiło kolosalny i picrwszy, wielki wyłom w rcżymic józefińskim na odcinku spraw kościelnych? Pierwsze trudności przyszly ze strony metropolity Ankwicza. Zażądał on bowiem od czlonków Towarzystwa Jezusowego calkowitego podporzadkowania się pod jego jurysdykcje, zgodnie z józefińskim prawem zakonnym. Od profesorów ginnazjalnych wymagał egzaminów ze wszystkich dyscyplin naukowych, które mieli wykładać, a jurysdykcję do spowiadania uzależnił od zdania odpowiednich egzaminów $z$ teologii moralnej i innych dyscyplin teologicznych. Niektórym ojcom, mimo zdane egzaminy, odmówil zezwolenia na podjęcie działalności kaznodziejskiej. Największą batalię stoczyl metropolita Ankwicz z Towarzystwem Jezusowym na temat zaangażowania 102 jezuitów, których chciał sekularyzować i wysłać na placówki duszpasterskie $w$ archidiecezji lwowskiej ${ }^{9}$.

A jaki był skutek takiego stanowiska metropolity Ankwicza? Na nieszczęście podpisany nie miał możliwości dotarcia do archiwaliów lwowskich z $1820 \mathrm{r}$. Wykorzystano jedynie archiwalia archidiecezjalne z $1821 \mathrm{r}$. i następnych lat. Wskazują one na to, że zaborczy arcybiskup zniweczył początkowo prawie całkowicie autonomię jezuitów. W 1821 r. zamieszkiwali głównie Tarnopol

9 F. Maass, Der Josephinismus, nr 5 s. 182-183, $73 \mathrm{n}$. 
w dawnym klasztorze podominikańskim wraz z kościolem, a także $w$ klasztorze dominikańskim $w$ Podkamieniu ${ }^{10}$. Zgodnie z potrzebami archidiecezji metropolita Ankwicz rozpocząl od początku 1821 r. obsadzanie jezuitami placówek pastoralnych. Tak 26 stycznia o. Stefan Rentt objąl wikariat w Sidorowie w dekanacie jazłowieckim, w sierpniu t.r. jezuici zaczęli przejmować duszpasterstwo w parafiach mieszanych narodowo na Bukowinie (Jakobeny) ${ }^{11}$. W 1821 i 1822 r. jezuici podjeli prace jako wikariusze lub administratorzy parafii $w$ Kosowie, Krzywczach, Lipsku, Pieniskach, Kamionce Strumiłowej, Tlustem, a także na Bukowinie iv Zastawnej, Fürstentahl i Kocmanie. W dniu 10 XII 1822 r. były prowincjał jezuitów o. A. Pierling, przejal administrację parafii Gura Humora na Bukowinie ${ }^{12}$. W 1823 r. przybyły dalsze placówki duszpasterskic w Szczercu, Nadwórnej i Rohatyniu. Dzialo się to wszystko w oparciu o dyspensę papieska i za zgoda prowincjala, o. Stanisława Świętochowskiego. Prawie w każdym wypadku w celu podtrzymania wspólnoty zakonnej na placówki parafialne udawało się dwóch jezuitów ${ }^{13}$. Na żądanie metropolity Ankwicza prowincjał Świętochowski dostarczył mu 21 czerwca 1821 r. pelny "spis jezuitów, znajdujacych się w archidiecezji lwowskiej", a na przesuniẹcia personalne w każdym przypadku prosił o zgodę Metropolitę ${ }^{14}$.

Obejmowane przez jezuitów parafie pod względem materialnym pozostawialy bardzo wiele do życzenia; warunki mieszkaniowe i życiowe były niezwykle trudne. Toteż prowincjał Świętochowski zaapelowal dnia 8 września 1821 r. do metropolity Ankwicza, by ten „wziąl pod swoja opiekę jezuitów przydzielonych do duszpasterstwa i przyszedl im $z$ pomocą $w$ celu polepszenia ich warunków mieszkaniowych i życiowych"15. Na prośbę prowincjała Świętochowskiego, wniesiona iv dniu 7 listopada 1821 r. metropolita Ankwicz zgodził się (24 listopada t.r.), by jezuici mogli się trzymać wlasnego kalendarza liturgicznego i obchodzić własne święta zakonne, a w czasie Wielkiego Postu 1822 r. korzystać z odpowiedniej dyspensy ${ }^{16}$.

Wydawalo się, że przynajmniej $\mathrm{w}$ wewnętrznych sprawach kolegium tarnopolskiego Towarzystwo Jezusowe będzie mialo więcej swobody działania. Ale i na tym odcinku nie bylo najlepiej. Dekretem Kancelarii Nadwornej

10 AAL (Archiwum Archidiecezji Lwowskiej w Lubaczowie) Protocollon exhibitonum Consistorii Metropolitant Leopoliensis ex anno $1821 \mathrm{nr} 538$ (19 II 1821).

11 Tamże, nr 396 (26 I), 1806 (27 VIII).

12 AAL Protocollon exhibitorun $1822 \mathrm{nr} 521$ (26 II), 1306 (3 VI), 1345 (4 VII), 1571 (8 VII), 2043 (9 IX), 2943 (10 XII), 3046 (17 XII), 3063 (21 XII), 3110 (31 XII); Protocollon exhibitorum $1823 \mathrm{nr}$ 453 (20 I 1823).

13 AAL Protocollon exhibitorum $1823 \mathrm{nr} 2146$ (11 IX); St. Zalęski, Jezulici s. 277.

11 AAL Protocollon exhibitorum $1822 \mathrm{nr} 1283$ (23 VI), 1668, 1813 (29 VIII).

15 AAL Protocollon exhibitorum $1822 \mathrm{nr} 1916$ (8 IX).

16 AAL Protocollon $1821 \mathrm{nr} 2439$ (7 XI), 2610 (24 XI); Protocollon $1822 \mathrm{nr} 249$ (30 I). 
z dnia 12 grudnia $1820 \mathrm{r}$. władze wiedeńskie określiły dokladnie takie oto warunki, na jakich jezuici mieli prowadzić gimnazjum:

1. dyrektor, względnie prefekt gimnazjum w Tarnopolu został uzależniony we wszystkich sprawach odnoszacych się do szkoły od starosty cyrkułowego;

2. kapłani Towarzystwa Jezusowego, którzy będą wyznaczeni na profesorów, są zobowiazani zdać odpowiednie egzaminy konkursowe przed dyrektorem gimnazjum państwowego;

3. prefekt winien przesłać władzom państwowym pisemną listę tych ojców Towarzystwa, którzy zlożyli egzaminy konkursowe wraz ze świadectwem dyrektora państwowego gimnazjum i odpowiednimi załącznikami personalnymi;

4. jak należy postạpić na przyszłość w stosunku do tych ojców, którzy podjęli obowiązki profesorów bez egzaminów konkursowych, Nadworna Komisja Studiów wyda odpowiednie zarządzenie ${ }^{17}$.

Tak więc w zakresie szkolnictwa jezuici zostali całkowicie podporządkowani władzom państwowym. Zlagodzono wszakże niebawem te warunki, jako że Nadworna Kancelaria w piśmie do gubernatora Galicji z grudnia 1820 r. postanowiła, że „na przyszlość jezuici moga być dyspensowani od tych egzaminów konkursowych, ale w wypadku, gdy z taką inicjatywa wystapi samo Gubernium lwowskie ${ }^{15}$.

$\mathrm{Na}$ domiar początkowych udręczeń wybuchł w 1822 r. spór między jezuitami a metropolita Ankwiczem na tle szafarstwa sakramentu pokuty. Jezuici zgodnie ze swoimi założeniami byli wzorowymi spowiednikami. Tymczasem Konsystorz Metropolitalny we Lwowie udzielil tylko trzem ojcom jurysdykcji w tym zakresie, łącznie „a casibus reservatis absolvendi”, a ponowna prośba prowincjała o podobne uprawnienia dla dalszych trzech jezuitów (4 maj 1822) nie wiadomo czy zostala zalatwiona pozytywnie ${ }^{19}$. Do wybuchu zatargu doszlo w lipcu 1822 r., kiedy metropolita Ankwicz w liście z 10 VII t.r. do prowincjala Świętochowskiego zaprotestował ostro przeciwko opuszczeniu bez jego wiedzy i zgody przez kilku jezuitów klasztoru dominikańskiego w Podkamieniu, a także przeciwko tym jezuitom, którzy „w Tarnopolu bez odpowiedniej aprobacji odważyli się spowiadać wiernych ${ }^{20}$. U źródel tego protestu leżalo przekonanie Metropolity, że zgodnie z reżymem józefińskim źycie zakonie jest calkowicie podponzadkowane jomu, jako ordynariuszowi archidiecezji Iwowskiej. W wyjaśnieniu bowiem prowincjala Świętochowskiego, skierowanym dnia 18 VII 1822 r. do Konsystorza Metro-

\footnotetext{
17 F. Maass, Der Josephinismus, Th. 5 s. 79 n.

18 HHSt. Wien. St. R. Protocollon 1820 nr 8189.

19 AAL Protocollon exhibitonum $1822 \mathrm{nr} 600$ (7 IV), 1063 (4 V).

20 AAL Protocollon 1822 nr 1959 (11 VII).
} 
politalnego we Lwowie, okazało się, że jezuici "nie opuszczali samowolnie klasztoru w Podkamieniu", ale zostali przeniesieni na inne placówki przez prowincjała, a zalączony przezeń katalog jezuitów tarnopolskich wykazywal że wszyscy mieli odpowiednie uprawnienia kościelne do przyjmowania spowiedzi od wiernych ${ }^{21}$.

Wysłanic kilku dalszych jezuitów na parafie i wryjaśnienie prowincjała uspokoilo nieco sytuację, a prośba jezuitów o otwarcie kaplicy domowej w Tamopolu, "gdzie starsi i słabsi kaplani mogliby celebrować Mszę św." (z 31 XIl 1822) została załatwiona przez Konsystorz lwowski pozytywnie ${ }^{22}$. Do dalszych osiagnięć zakonu w latach 1821-1822 należy zaliczyć zaproszenie ich przez biskupa przemyskiego A. Golaszewskiego do Starej Wsi koło Brzozowa, gdzie oddal im klasztor popauliński i do Tuchowa koło Tarnowa, gdzie zamieszkali w klasztorze pobenedyktyniskim. W Starej Wsi jezuici w liczbie 41 objęli klasztor w dniu 23 XII 1821 r., a w styczniu 1822 r. za zgodą ces. Franciszka I otwarli tu nowicjat. W Tuchowie zamieszkali jeszcze w maju 1821 r. w liczbie sześciu ojców przy dawnym klasztorze benedyktyńskim, gdzie obowiazki ekspozyta pelnił dawny benedyktyn, ks. Bernard Ganther ${ }^{23}$.

Przykre jednakże doświadczenia we wspólpracy z Metropolitą Ankwiczem, które wróżyly calkowitą utratę wewnętrznego ustroju, kazały prowincjałowi Świętochowskiemu szukać ostatecznego zabezpieczenia zakonu w Wiedniu. W dniu 20 maja 1822 r. skierowal on pismo iw tej sprawie do Nadwornej Kancelarii Cesarskiej w Wiedniu. W liście tym prosił:

1. o zezwolenie, by generał Towarzystwa Jezusowego mógl bez przeszkody mianować i zmieniać przełożonych lokalnych i prowincjała w Galicji, oraz by iv zarządzie Towarzystwa mógł korzystać z tych wszystkich uprawnień, które mu przyznają reguly Instytutu. Prosił również, by każdy z czlonków Towarzystwa mógl bez przeszkód znosić się z generalem w tych sprawach, które dotycza życia wewnętrznego i zakonnej karności. W dalszej kolejności prosil, by on, prowincjal, mógl zgodnie z przepisami Instytutu swobodnie wyznaczać zakonników na urzędy i by takaż swoboda w tym zakresie przysługiwała generałowi zakonu;

2. prosił też prowincjał o potwierdzenie tych punktów reguły Instytutu, które mu zezwalaja $z$ bardzo ważnych powodów, lub dla dobra zakonu usuwać niektórych zakonników z Instytutu bez zwracania się $w$ tej sprawie do innych urzędów;

3. wykazywal nadto, że zgodnie $z$ reguła Towarzystwa nie jest dozwolone składanie uroczystych ślubów przed 30, a najczęściej przed 33 rokiem życia.

21 Tamże, nr 1652 (18 VII), 2533 (7 XI).

22 AAL Protocollon exhibitorum $1822 \mathrm{nr} 3107$ (31 XII).

23 St. Zalęski, Jezuici, s. 294 d., 297 n. 
Przed tỵm rokiem czlonkowie Towarzystwa moga składać śluby proste po ukoniczeniu dwuletniego nowicjatu. Prosil więc, by $w$ takich wypadkach ślubów prostych mógl zwalniać sam przełożony ${ }^{24}$.

List ten Kancelaria Nadworna przekazała księciu arcybiskupowi wiedeńskiemu Leopoldowi hr. Firmianowi (1822-1831) z prośbą o odpowiednie uwagi. Arcybiskup po przestudiowaniu listu stwierdzil, że józefińskie przepisy zakonne z 24 III 1781 i z 1 V 1782, a także z 24 III 1783 r., dotyczace kontaktu zakonów austriackich $z$ przelożonymi generalnymi $w$ Rzymie sa zupełnie sprzeczne z postulatami prowincjała Świętochowskiego, które zostały objęte punktem nr 1. Uważal jednak, że zakon ma prawo usunąć ze swego gremium zakonnika. Nie widział też żadnych przeszkód do składania czasowych ślubów zakonnych, jako że "vota simplicia nie pociagaja za sobą żadnych konsekwencji ani kanonicznych, ani obywatelskich". Stwierdzał jednak, że "dotad nie bylo żadnego wypadku i żadnego wyjatku" dla ścisłej łączności między zakonem w Austrii a generalem tegoż zakonu w Rzymie. Ponieważ lączność ta należy do istotnej struktury Towarzystwa Jezusowego, pisal dalej arcybiskup Firmian, „dlatego nie pozostaje nic innego, jak wypędzić jezuitów z Austrii lub im zezwolić na swobodna lączność z generałem zakonu". Zwracal jednak uwagę na fakt czy konstytucje zakonu nie zezwalaja na wybór wikariusza generalnego dla zakonu $w$ Austrii, podobnie jak to miało miejsce dla redemptorystów. Odnośnic do punktów nr 2 i $3 \mathrm{w}$ liście prowincjala Arcybiskup uważal, że „bez zwloki należy na nie jezuitom zezwolić” 25 .

Ale uwagi arcybiskupa Firmiana nie zadowolily kanclerza hr. Saurau, dlatego zażądal od prowincjała Świętochowskiego dalszych wyjaśnień. Wysłal je on $z$ Tarnopola $w$ dniu 13 stycznia $1823 \mathrm{r}$. List ten $w$ gruncie rzeczy był prawie $w$ całości poświęcony szerokim uprawnieniom generała $w$ sprawach zakonu, które - jak mocno podkreślal - "należą do fundamentalnych podstaw strukturalnych Towarzystwa Jezusowego", "a jeżeli ono cokolwiek dobrego zrobilo, to mogło się to stać tylko dlatego, że z cała sumiennościa przestrzegano konstytucji Towarzystwa" ${ }^{\prime 26}$.

Nagromadzony $w$ ten sposób bogaty materiał wraz $z$ konstytucjami jezuickimi stal się przedmiotem posiedzeń i dyskusji Nadwornej Kancelarii Cesarskiej w Wiedniu w lutym 1823 r. Po stronie jezuitów bylo nade wszystko stwierdzenie pisemne ces. Franciszka I w liście do téjte Kancelarii z 12 V'ill 1820 r., że „jezuitom jako takim („Jesuiten als solchen”) należy przekazać zaklady naukowo-wychowawcze w Galicji". Przeciwko zaś nim zwracał się patent cesarski z 20 VIII 1820 r., który obiecywal im wprawdzie dyspensy,

24 F. Maass, Der Josephinismuls. Bd 5 nr 9 s. 206.

25 Tamże, nr 9 s, 206-207.

26 Tamże, nr 9 s. 207-209. 
ale polecal też przestrzeganie krajowych praw in publico ecclesiasticis. Jakież wnioski stawiala Kancelaria Nadworna dla ewentualnego patentu cesarskiego? W piśmie z 6 lutego 1823 r. Kancelaria ta poddawała wniosek:

1. by w porozumieniu ze Stolicą Święta spowodować przekazanie pełnomocnictw generala Zakonu na reprezentantów jego w Cesarstwie Austriackim;

2. by zgodzić się na vota simplicia u jezuitów, ale pod takimi warunkami, jakie sa wymagane dla ślubów uroczystych;

3. by zwolnienie profesów z zakonu mogło następować wówczas, gdy zwalniany będzie przyjęty do innego zakonu lub diecezji, lub też gdy się mu zapewni środki utrzymania w wypadku, gdyby nie był zdolny do podjęcia pracy kościelnej"․

Decyzja cesarska rodziła się powoli; podjał ja osobiście ces. Franciszek I dopiero w dniu 13 września 1824 r. i została ona skierowana do Tarnopola na ręce prowincjała jezuitów. Jak można było się spodziewać decyzja ta uwzględniała niektóre postulaty jezuitów, ale w zasadzie stała na gruncie józefińskiego prawa zakonnego. Postanawiala więc:

1. w sprawach kontaktów jezuitów galicyjskich $z$ generałem w Rzymie miały nadal obowiązywać przepisy józefińskie w tym zakresie. Cesarz jednak się zgadzał, by generał zakonu mianował swego wikariusza dla krajów austriackich, lub też sam zamieszkal w granicach Cesarstwa. Kolegia jezuickie mialy nadal pozostawać pod nadzorem ordynariusza miejscowego;

2. jezuici moga usuwać z zakonu własnych czlonków i nie troszczyć się o dalsze ich zaopatrzenie. Usuniętych jednak należy zatrzymać w jednym z kolegiów do określonego czasu i o tym wszystkim powiadomić wladze gubernialne;

3. w sprawie ślubów prostych i uroczystych należy się trzymać konstytucji zakonnych;

4. kolegium, które zatrudnia jezuitów wygnanych z obcych prowincji (Rosji) winno przeslać odpowiednią relacje o ich zawodzie i wieku do gubernium krajowego, gubernium zaś relacje te $z$ wlasnymi uwagi winno przesłać do Nadwornej Kancelarii Cesarskiej, a ta ma je przekazać do decyzji cesarzowi;

5. odnośnie profesorów i nauczycieli z zakonu jezuitów należy stosować przepisy prawa krajowego, wydane wcześniej dla pijarów i innych zakonów regularnych, zatrudnionych $w$ nauczaniu;

6. jezuici moga zorganizować i otworzyć wlasne domowe studium filozoficzno-teologiczne, ale przy zachowaniu przepisów państwowych w tym zakresie $^{28}$.

27 Tamże, nr 9 s. 209-212.

28 Tamże, nr 9 s. 212-213. 
Decyzje cesarskie stanowily niewatpliwie postęp $w$ stosunku do sytuacji prawnej zakonów $w$ Austrii, ale to nie bylo to, o co oni zabiegali. Toteż przez caly rok 1823 pozostawali pod stala kontrola nieustępliwego metropolity Ankwicza. Informowali go więc o zmianach na urzędzie superiora w Tarnopolu (1 III), przesłali mu do zaakceptowania listę kandydatów do nowicjatu (2 IV), powiadamiali o wszelkich zmianach personainych (8 IX), prosili o pośredniczenie u wladz Funduszu religijnego (7 IV), zabiegali o zezwolenie na odprawienie rekolekcji dla poszczególnych jezuitów zajetych $w$ duszpasterstwie (11 IX) itp..$^{29}$. Równocześnie coraz to mocniej urzadzali się $w$ diecezji przemyskiej, zwlaszcza w Starej Wsi (182?) Tuchowie (1821) i Łańcucie (1820) ${ }^{30}$. Już w 1821 r. postawili pierwsze kroki w Wikariacie Starosądeckim, odkąd 20 II 1921 r. o. Karol Snarski otrzymal tu jurysdykcje do spowiadania i szafarstwa innych sakramentów św. W następnych latach, już po utworzeniu diecezji tynieckiej (przeniesionej w 1825 do Tarnowa) za zgoda biskupa G.T. Zieglera, obok Tuchowa, który znalazl się $w$ granicach diecezji od 21 IX 1821 r., jezuici podjeli prace pastoralna $w$ charakterze wikariuszy $w$ Mielcu, Myślenicach, Pilźnie, Sulkowicach, a od 1824 r. w Bochni, Zalasowej i Podegrodziu kolo Nowego Sacza, gdzie pracowal o. P. Hawrylewicz w latach $1824-1826^{31}$.

Kiedy przeniesienie stolicy diecezji z Tyńca do Tarnowa stało się faktem dokonanym (1825), wówczas prowincjal jezuitów zaczal zabiegać u władz austriackich o przekazanie jezuitom opactwa pobenedyktyńskiego $w$ Tyńcu. Stalo się to już 15 XI 1826 r. przy walnym poparciu biskupa G.T. Zieglera, a decyzja ces. Franciszka I w tym względzie została podpisana $w$ dniu 20 XI $1826 \mathrm{r}$. Jezuici urządzili tu studium teologiczne. Uroczyste oddanie opactwa przez biskupa Zieglera $w$ ręce jezuitów nastapiło $w$ dniu $25 \mathrm{~V} 1827 \mathrm{r}^{32}$ Głęboko religijny biskup Ziegler, jeden z glównych filarów restauracji katolickiej $w$ Austrii ${ }^{33}$ byl zakonowi niezwykle oddany. Dał temu wyraz w relacji - stanie diecezji do Rzymu z dnia 5 XII 1826 r., w której m.in. pisal: „O księżach i braciach Towarzystwa Jezusowego, którzy za zgodą władz państwowych przybyli tu z Białorusi, napiszę osobno. Ale już dziś nie mogę nie stwierdzić, że tam, gdzie się pokaża, sa jak Aniołowie z nieba i Aniołowie pokoju, świetlisty wzór karności zakonnej i przykladami prawdziwej

${ }^{29}$ AAL Protocollon exhibitorum 1823 nr 532 (1 III), 779 (2 IV) 816 (7 IV), 2082 (8 IX), 2146 (11 IX), $2511(25 \mathrm{X})$.

30 St. Zalęski, Jezuici, s. 294-299.

31 ADT (Archiwum Diecezjalne w Tarnowie) Protocollum exhibitorum Consistorii episcopalis Tynencensis ex amo $1821 \mathrm{nr} 76$; Protocollum exhibitorum Contsistorii episcopalis Tamotiensis ex anno $1826 \mathrm{nr} 863,864$.

32 ADT Protocollum exhibitorum $1826 \mathrm{nr}$ 1971; Protocollum exhibitorum $1828 \mathrm{nr}$ 1225; St. Zalęski, Jezuici, s. 299 n.

${ }^{33}$ E. Winter, Frihliberalismus in der Donaumonarchie. Berlin 1968 s. 89, E. Tomek, Kirchegeschichte, Th. 3 s. $646 \mathrm{nn}$. 
pobożności. Pracując $w$ duszpasterstwie parafialnym przez swoje niezrównane kazania, katechizację wieśniaków, słuchanie spowiedzi zapalili w sercach wiernych ogień autentycznej religijności ${ }^{34}$. To dzięki inicjatywie tego Biskupa jezuici założyli misje w Staniątkach kolo Krakowa (1828), a także rozpoczęli starania u czynników rządowych już w 1826 r. o przekazanie im ponorbertańskiego klasztoru i kościola Ducha Świętego w Nowym Saczu. Stało się to nieco później, już w okresie rządów biskupa Franciszka a Paulo Piśteka. Placówkę tę przejęli w dniu 10 VI 1832 r., dokąd przyszli z prowizorycznej rezydencji $w$ Wieliczce, po spaleniu się opactwa tynieckiego $(1831)^{35}$. W $1833 \mathrm{r}$. jezuici byli gotowi przeją́ klasztor poaugustiański w Pilźnie, dokąd za zgoda gubernium lwowskiego zapraszal ich biskup Piśtek ${ }^{36}$. Oni też za zgoda wikariusza kapitulnego diecezji tamowskiej, ks. Jana Fukiera, wprowadzili w 1828 r. po raz pierwszy w diecezji święto Najśw. Serca Jezusowego w niedzielę po Oktawie Bożego Ciala ${ }^{37}$.

W międzyczasie na skutek interwencji prymasa Wegier kard. Aleksandra Rudnaya (-1839), biskupa Zieglera, a nade wszystko radcy dworskiego Józefa Antoniego Pilata, nie bez pewnego poparcia księcia K.L.W. Metternicha, ces. Franciszek I zdecydowal się, by w dniu 18 XI $1827 \mathrm{r}$. ogłosić „wielką kartę wolności” dla galicyjskich jezuitów. W liście z tego dnia, skierowanym na ręce gubernatora Galicji Augusta Longina Lobkowitza (1826-1832), cesarz stwierdzal, iż "w jego Królestwie Galicji jezuici podjęli konieczna pracę na odcinku nauczania i wychowywania mlodzieży, a także na polu duszpasterskim, na skutek czego polożyli tamę niewierze i niemoralności, a mlodzież wychowuja na dobrych chrześcijan i lojalnych obywateli, przyczyniajac się $w$ ten sposób do rozwoju kultury i szczęścia jego poddanych". On też sam "pragnąc wyjść na przeciw ich uzasadnionym prośbom, zgadza się, by $w$ królestwie Galicji mogli żyć zgodnie $z$ ich konstytucjami zakonnymi i skladanymi przez nich ślubami". W związku z powyższym zezwalał:

1. by utrzymywali bezpośrednie kontakty $z$ generalem zakonu, jak tego wymagaja konstytucje Instytutu, we wszystkim co dotyczy wewnętrznego zarzadu i zachowania karności;

2. by we wszystkich sprawach duszpasterskich, a więc w zakresie urządzanych nabożeństw, kaznodziejstwa, szafarstwa sakramentów i czasowej pomocy pastoralnej podlegali miejscowym biskupom;

${ }^{3+}$ Relacje o stanie diecezii tarnowskiej $z$ lat 1791-1863. Wyd. ks. B. Kumor. "Archiwa, Biblioteki i Muzea Kościelne". T. 33, 197 s. 401.

35 ADT Protocollum exhibitorum $1826 \mathrm{nr} 1044$ (Nowy Sącz); Protocollum exhibitorum $1828 \mathrm{nr}$ 1439, 1519 (Staniatki); Protocollum exhibitorum $1831 \mathrm{nr} 1147$ (Wieliczka - „provisorie locati”); Protocollum exhibitorum $1832 \mathrm{nr} 1727$ (Nowy Sacz); Schematismus universi denerabilis cleri Dioceseos Tarnoviensis ... a.s. 1834 s. 19 (Tuchów), 50 (Staniątki), 72 (Nowy Sacz); St. Sygański, Jezuici, s. $301 \mathrm{n}$.

36 ADT Protocollum exhibitorum $1833 \mathrm{nr} 1737$. 
3. by poszczególni czlonkowie zakonu, pracujacy w duszpasterstwie, w celu zachowania formy życia zakonnego pracowali tam $w$ formie zorganizowanej misji przez prowincjala i ordynariusza miejsca;

4. by domowe studia teologiczne jezuitów stosowaly się do rozporządzeń cesarskich z dnia 24 VIII 1827 r. W prowadzeniu kolegiów cesarz zgadzal się, by byly prowadzone zgodnie $z$ własnymi przepisami Instytutu Towarzystwa Jezusowego. Używane wszakże przez nich podręczniki do studiów teologicznych winny mieć specjalne zezwolenie urzędów państwowych. Podobnie wedlug przcpisów państwowych winny się odbywać egzaminy uczniowskie;

5. by w wypadku wyjazdu poza granice Cesarstwa, lub przyjazdu do Austrii, prowincjal postaral się każdorazowo o decyzje cesarska $w$ tym zakresie;

6. decyzje cesarską należało podać do wiadomości gubernatorowi galicyjskiemu, a także prowincjałowi jezuitó $w^{38}$.

Postanowienie cesarskie $\mathrm{z}$ dnia 18 XI 1826 r. stanowiło najpoważniejszy wylom $w$ reżymie józefińskim na przestrzeni ostatnich 50 lat i właściwie przekreślalo całe józefińskie prawodawstwo zakonne. Budowany prawie przez 80 lat system ujarzmiania Kościoła przez państwo zaczął gwaltownie pękać i rozsypywać się, jako że okazal się nieżyciowy zarówno dla spoleczeństwa, jak i dla Kościola szkodliwy. Ostatecznie odrzucil go ces. Franciszek Józef I patentem z dnia 4 II $1849 \mathrm{r}^{39}$ Jedną $\mathrm{z}$ głównych sil, które obaliły ten szkodliwy, biurokratyczny system byli jezuici polscy z Galicji.

37 ADT Protocollum exhibitorum 1828 nr 950.

38 F. Maass, Der Josephinismus. Bd 5 nr 12 s. 250-254 (10 X 1825), nr 18 s. 261-263 (10 I 1827), nr 20 s. 271-272 (18 XI 1827).

39 Tamże, Th. 5 nr 121 s. $741-742$. 